\title{
CLASSROOM INTERACTION WITH DIFFERENT SUBJECT BASED ON SINCLAIR AND COULTHARD MODEL
}

\author{
AN ARTICLE \\ Submitted in Partial Fulfillment of the Requirements \\ for the Degree of Sarjana Pendidikan
}

By:

INDAHWATY SUWANDY

Registration Number: 2131121010

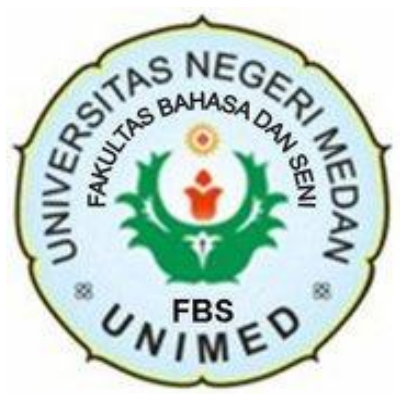

ENGLISH AND LITERATURE DEPARTMENT

FACULTY OF LANGUAGES AND ARTS STATE UNIVERSITY OF MEDAN

2018 
ARTIKEL

\title{
CLASSROOM INTERACTION WITH DIFFERENT SUBJECT BASED ON SINCLAIR AND COULTHARD MODEL
}

\author{
Disusun dan Diajukan olch: \\ Indahwaty Suwandy \\ NIM. 2131121010
}

Telah diverifikasi dan dinyatakan memenuhi syarat

untuk diunggah pada jurnal online

Medan, $\quad$ Maret 2018

Menyetujui

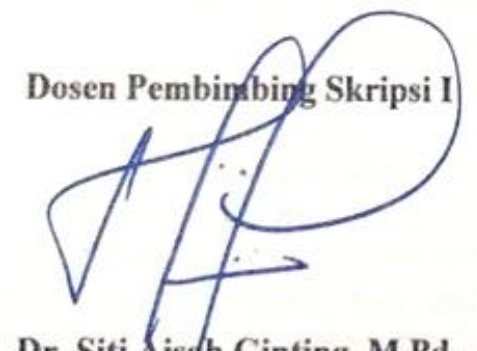

Dr. Siti Aisah Ginting, M.Pd. NIP. 195705211984032002
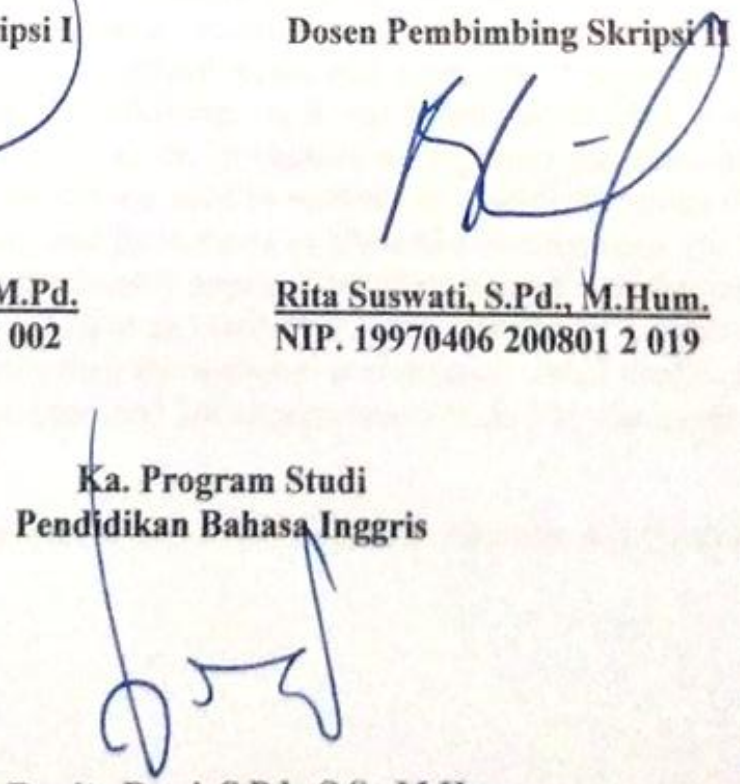

Nora Ronita Dewi, S.Pd. S.S M.Hum.

NIP. 198005222008122003 


\title{
CLASSROOM INTERACTION WITH DIFFERENT SUBJECT BASED ON SINCLAIR AND COULTHARD MODEL
}

\author{
*IndahwatySuwandy \\ **SitiAisahGinting \\ **RitaSuswati
}

\begin{abstract}
ABSTRACT

Suwandy, Indahwaty. Registration Number: 2131121010. Classroom Interaction with Different Subject Based on Sinclair and Coulthard Model. A Thesis. English Educational Program, Faculty of Language and Arts, State University of Medan, 2018

This study is analysis of classroom interaction between English and Mathematics subject which conducted by teachers and students through communication in classroom interaction. The aims of this study were: (a) To identify the kinds of Initiation-Response-Feedback (IRF) pattern are used by the teacher and students in classroom interaction based on Sinclair and Coulthard Model (1975), and (b) To find out why the Initiation-Response-Feedback (IRF) pattern is dominant in classroom interaction through different subject. The design of the research used qualitative research. To answer the problem of study, the data collected through the following instrument: observation, recording and interviewing which were analyzed by using Sinclair and Coulthard model and a concept of teaching. The results of this research were the following, (a) it was found that in English and Mathematics classroom discourse, as the IR (Initiation-Response) was used more often by teachers and I (Initiation) was used by students in English classroom then IF (Initiation-Feedback) was used by students in Mathematics classroom, (b) the reason why the IRF pattern dominantly appeared based on teacher's performance which dominantly initiated questions and information was affected by the presage category and context category then the students' performance which dominantly responded the teachers' questions and information was affected by the students' thought processes category.
\end{abstract}

Key words: Classroom interaction, classroom discourse, Sinclair and Coulthard Model, IRF Pattern.

\footnotetext{
* Graduate

** Lecturer
} 


\section{INTRODUCTION}

\section{Background of the Study}

Classroom is not simply a place teaching-learning process is undertaken and it is a place where the teacher just carries out predetermined routines and gives a task or explains the materials, but rather than a place where various elements interaction and communication. These elements are the teacher with his/her educational background, the students, experience, knowledge, expectation and the activity in the classroom.

Teaching and learning process can succeed through the interaction and communication in the classroom among teacher and students as the cognitive process of constructing knowledge and developing competency to understand, reason, and solve problem (Markee, 2015: 96). Therefore, communication system happens based on the interaction among teacher and students in the classroom.

Based on author's observation in SMA Negeri 16 Medan, the students really seldom participate in a classroom interaction due to their lack of conversation as the signals of their interactions with each other and the teacher. Firstly, they did not know how to respond in English. Secondly, the students were not confident to say in English. Then, students often used Indonesian language to respond. The interaction also showed that only one source of teaching occurred that was the teacher herself. The teacher dominated the classroom interaction with few responds from the students. It means that there is no response from students and also the feedback. 
By understanding and analyzing classroom discourse, it makes the teacher understands; how to initiate the question in order to create the communication and there will be response from the students based on teacher's question indirectly. Then, it will be analyzed by Sinclair and Coulthard, borrowing from Halliday's theory of scale and category grammar by developing ranks at the discourse level which is in descending order: Lesson, Transaction, Exchange, Move, and Act. After that, it also has a tripartite structure which is called IRF; the teacher initiates, the pupils responds, the teacher then evaluate the response (Sinclair and Coulthard, 1992: 2)

Nowadays, mathematics belongs to passive students who never speak actively in the classroom and they just think and practice the questions. Therefore, it is caused the interaction among teacher and students in the classroom. So, the researcher wants to know and does research with different subject to see the interaction and discourse pattern happens. Focusing on the analysis could be expected to show useful findings which would contribute to deeper insights about the ways to improve English teaching and learning, especially in creating classroom procedure which meets student goals of secondary language proficiency.

To conclude that classroom discourse analysis is useful for a teacher to understand the form of discourse classroom pattern. The teacher will get the understanding of the ways questions must be asked, response can be answered, and it can give feedback. This study aids their teaching that will encourage 
interactions among students especially for EFL classroom in teaching learning process.

\section{REVIEW OF LITERATURE}

\section{Classroom Interaction}

Classroom Interaction among teacher and students is the main focus of the research. Classroom can be characterized and described by looking at a range of interactional features such as teacher elicitation strategies, learner responses and teacher evaluations (Walsh, 2011:25).

\section{Classroom Discourse Analysis}

Discourse analysis is the study of relationship between language and the contexts in which it is used. Discourse analysis uses in: written texts of all kinds, and spoken data, from conversation that can be used to in constructing and communicating meaning and knowledge as they learn to apply their knowledge (Markee, 2015:97).

\section{Sinclair and Coulthard Model}

One important study was carried out at the University of Birmingham by Sinclair and Coulthard (1975), who developed a model for the description of teacher-pupil talk based on a 1988: 56) ranked scale approach. The discourse level involves five ranks: Lesson - Transaction - Exchange - Move - Act.

Exchange generally consists of the IRF (Initiate-Response-Feedback) exchange pattern and is realized by eliciting, informing, and directing moves. Exchange then, is made up of a number of moves. In particular from of classroom interactions, the teaching exchanges, is considered among the most frequently 
occurring types of teacher-student talk in the classroom which is called InitiationResponse-Feedback (IRF) - an initiation by the teacher, followed by a Response from the student, followed by Feedback to the student's response from the teacher. Initiation is the opening of discourse, response is the answer or reply of the discourse and Feedback is the follow-up from the Response which is conducted mostly by teacher and very rarely by student.

4. Conception of teaching

In the teaching process, there are some categories that refer to the variables which might affect to each other in the classroom where the teaching process takes place, Gage (2009:47).

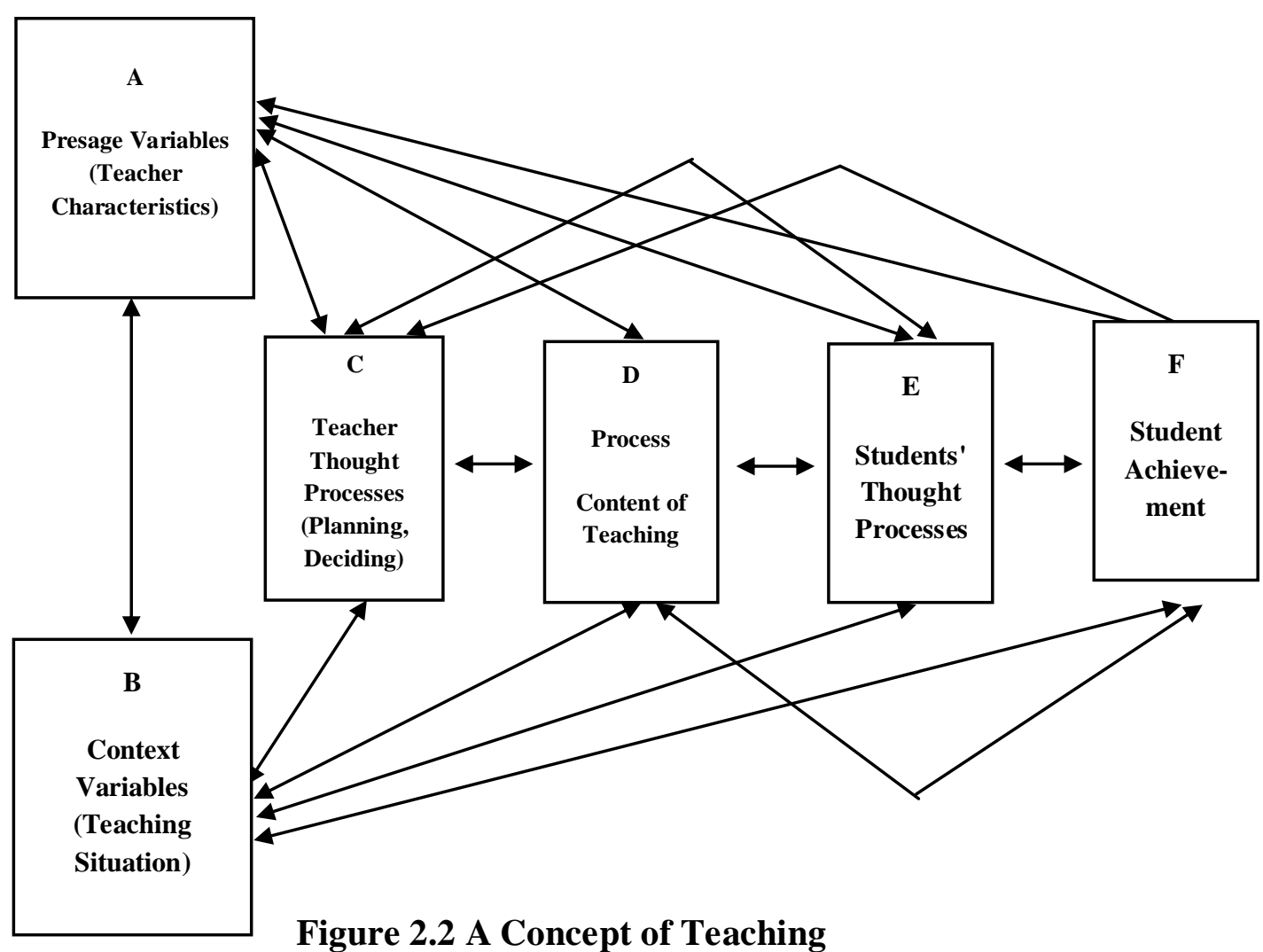




\title{
RESEARCH METHODOLOGY
}

\author{
Research Design
}

The research discusses classroom interaction study which focuses on the classroom discourse use Sinclair and Coulthard model. This research will be conducted by using qualitative research. Qualitative research is research that involves analyzing and interpreting texts and interviews in order to discover meaningful patterns descriptive of a particular phenomenon (Auerbach and Silverstein, 2003:3)

\section{Data and Source of Data}

The data of this study was utterances which are produced by the teachers and students through different subject in classroom interaction. The source of data was the transcription of spoken interaction among the teacher and students at the first grade students in SMA Negeri 16 Medan during the English language classroom. It will be recorded naturally in the classroom environment.

\section{The Instrument for Collecting Data}

The source of data was the transcription of spoken interaction among the teacher and students at the first grade students in SMA Negeri 16 Medan during the English language classroom. It will be recorded naturally in the classroom environment.

\section{Techniques for Collecting Data}

1. That was focused in the classroom, observation helped researchers understand the physical, social/cultural, and linguistic contexts in which language is used. 
2. Using video and audio recording to capture the classroom interaction and the talk among students and teacher. Next, the writer made the transcription which was analyzed by Sinclair and Coulthard (1975) model of classroom discourse.

3. Interviewing is an important way for a researcher to check the accuracy and find out what is on their minds or how they feel about something.

\section{Techniques for Analyzing Data}

1. Recording real classroom interaction.

2. Observing interaction and making preliminary observations.

3. Transcribing the verbal interaction.

4. Analyzing transcripts by using Sinclair and Coulthard model (1975).

5. Conducting the interview section to the English teacher and the students.

6. Giving the reasons for the existences of the dominant IRF model pattern.

7. The conclusion is drawn from the data that have been summed up.

\section{DATA AND DATA ANALYSIS}

The data of this study were utterances taken from the interaction between the English and mathematics teachers and the result of interviewing both teachers. This study focused on three elements which consisted of the IRF (InitiateResponse-Feedback) exchange pattern.

\section{FINDINGS}

From the analysis, it was found that the IRF pattern was dominant is IR pattern in Both English classroom and Mathematics classroom during the teaching 
learning process. There are 131 utterances which were uttered by English teacher as the percentage of IRF pattern and there were 123 utterances were produced by Mathematics teacher as the percentage of IRF pattern.

Table 4.1

The Frequency and Percentage of IRF Model Pattern (Initiation, Response and Feedback) of English and Mathematics Teachers in Classroom Interaction

\begin{tabular}{llllllll}
\hline No & $\begin{array}{c}\text { The IRF } \\
\text { pattern } \\
\text { in } \\
\text { English } \\
\text { Subject }\end{array}$ & $\begin{array}{c}\text { Frequenc } \\
\mathbf{y}\end{array}$ & $\begin{array}{c}\text { Percentag } \\
\mathbf{e}\end{array}$ & $\mathbf{N o}$ & $\begin{array}{c}\text { The IRF } \\
\text { pattern in } \\
\text { Mathemati } \\
\text { cs Subject }\end{array}$ & $\begin{array}{c}\text { Frequenc } \\
\mathbf{y}\end{array}$ & $\begin{array}{c}\text { Percentag } \\
\mathbf{e}\end{array}$ \\
\hline 1 & I & 43 & 32.82 & 1 & I & 32 & 26.01 \\
\hline 2 & IR & 64 & 48.85 & 2 & IR & 64 & 52.03 \\
\hline 3 & IRF & 24 & 18.32 & 3 & IRF & 27 & 21.95 \\
\hline & Total & 131 & & & Total & 123 & \\
\hline
\end{tabular}

Table 4.1 above shows the total number, percentages of IRF pattern, and the existences of free exchange based on Sinclair and Coulthard model produced by English and Mathematics teachers.

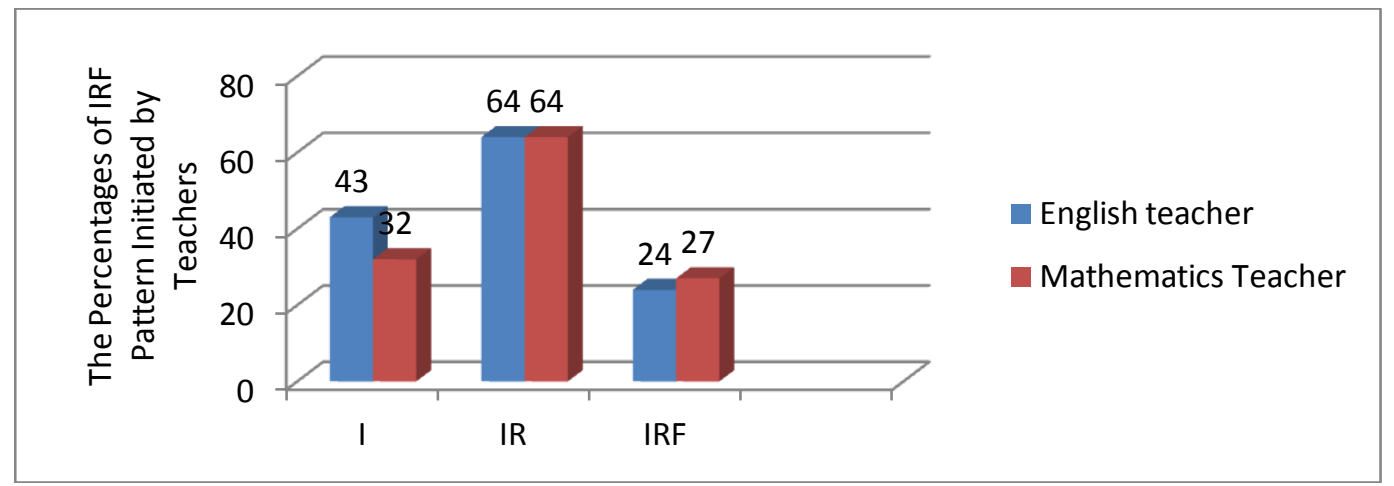

Figure 4.1 The Percentages of IRF Pattern initiated by English and Mathematics Teachers

Figure 4.1 shows the percentages of IR pattern was the most contributive pattern to the teaching and learning process. There were 131 utterances produced 
by the English teacher accounting for $48,85 \%$ on average and there were 123 utterances produced by Mathematics teacher with $52.03 \%$.

Meanwhile, students produced the total utterances that uttered were 127 utterances and I pattern was dominantly performed by English students. Then, The total utterances that uttered by Mathematics students were 70 utterances and IF pattern was dominantly performed by students.

Table 4.2

The Frequency and Percentage of IRF Model Pattern (Initiation, Response and Feedback) of English and Mathematics Students in Classroom Interaction

\begin{tabular}{llllllll}
\hline No & $\begin{array}{c}\text { The IRF } \\
\text { pattern } \\
\text { in } \\
\text { English } \\
\text { Subject }\end{array}$ & $\begin{array}{c}\text { Frequenc } \\
\text { Sn }\end{array}$ & $\begin{array}{c}\text { Percentag } \\
\text { e }\end{array}$ & No & $\begin{array}{c}\text { The IRF } \\
\text { pattern in } \\
\text { Mathemati } \\
\text { cs Subject }\end{array}$ & $\begin{array}{c}\text { Frequenc } \\
\mathbf{y}\end{array}$ & $\begin{array}{c}\text { Percentag } \\
\text { e }\end{array}$ \\
\hline 1 & I & 44 & 34.64 & 1 & I & 16 & 22.85 \\
\hline 2 & IR & 29 & 22.83 & 2 & IR & 19 & 27.14 \\
\hline 3 & IF & 35 & 27.55 & 3 & IF & 22 & 31.42 \\
\hline 4 & IRF & 19 & 14.96 & 4 & IRF & 13 & 18.57 \\
\hline & Total & 127 & & & Total & 70 & \\
\hline
\end{tabular}

Table 4.2 above shows the total number, percentages of IRF pattern, and the existences of free exchange based on Sinclair and Coulthard model produced by English and Mathematics students.

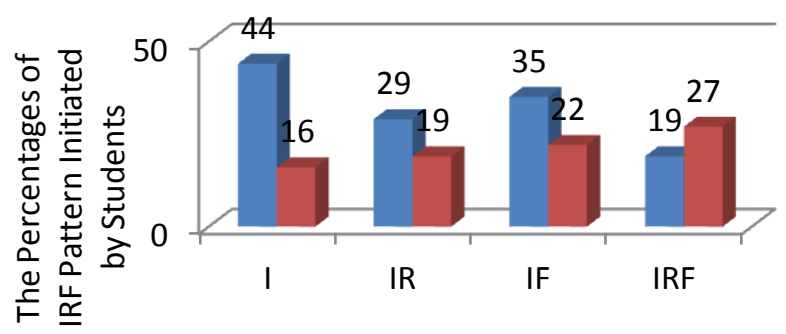

English Students

Mathematics Students

Figure 4.2 The Percentages of IRF Pattern Initiated by English and Mathematics Students 
Figure 4.2, there were 127 utterances produced by the English students and there were 70 utterances produced by Mathematics students. For all pattern which was initiated by the English students was I (initiation) pattern, 44 utterances $(34,64 \%)$ were only appeared in the main activities during the discussion time and discussion the tasks. The pattern was really dominant used by the Mathematics students was IF (initiation-feedback) pattern, 22 utterances (31,42 $\%)$ were only appeared in the main activities when students initiated and informed then the teacher gave the feedback.

In contrast, there were no significant differences between English and mathematics subject during the teaching learning process. It has many similarities between the two subjects. Both classes, either English or Mathematics subjects used IR pattern dominantly in the classroom interaction. Meanwhile, for English students mostly used I pattern and Mathematics students used IF pattern in the classroom.

According to the conception of teaching proposed by Gage (2004), there are variables: (a) presage category; (b) context category; (c) process category; and (d) product which might affect to one another on the teacher's and performance. The data from the interview sessions of teachers below shows the reason for the existences of the dominant types of IRF pattern produced by teachers. From the data was gained that Initiation-Response (IR) is used dominantly by English and Mathematics teachers which related to (a) presage category; and (b) context category where the teacher's beliefs belong to the presage category and the 
classroom situation in which the teaching process takes place belong to the context category.

According to the conception of teaching proposed by Gage (2004), there are variables: (a) presage category; (b) achievement category; which might affect to one another on the students' performance. The data from the interview sessions of students below shows the reason for the existences of the dominant types of IRF pattern produced by the students. From the data was gained that Initiation (I) in English subject and Initiation-Feedback (IF) in Mathematics subject were used dominantly by English and Mathematics teachers which related to (a) presage category; where the students' understanding and perception belong to the presage category.

\section{DISCUSSION}

By applying classroom discourse analysis based on Sinclair and Coulthard Model (1975) to the analysis of the classroom interaction taking place between the English and Mathematics teachers and students in classroom of X MIA1 and 2 SMAN 16 Medan. It was found that the model can be applied because the data tend to be fit into Sinclair and Coulthard Model (1975).

Based on the findings of this study was that English and Mathematics were interactive and attractive during the teaching learning process. They found their own problem which was the same as each other but one thing was the teachers did not give any feedback based on students' initiation. Meanwhile, the study above 
said if teachers give feedback it can increase and encourage them to make more vivid class between English and Mathematics class either students or teachers.

Teachers who have implemented Sinclair and Coulthard Model's step in the classroom interaction but both classes are often used with various reasons which reflect to the context and presage category. Beside that, the reason why two more categories do not belong to the reason of English and Mathematics students in using IRF model pattern because this study only focused on free exchange of IRF model pattern. In English subject, the teacher's reason Initiation-Response (IR) gave the positive impact in order to make the students active and involve in the classroom in upgrading the lesson and knowledge. In Mathematics subject, the teacher's reason Initiation-Response (IR) gave the positive impact in order to make the students understand about the lesson and they can respond the teacher's questions and create the vivid classroom.

\section{Conclusion}

1. Teachers mostly used teacher inform (IR) in classroom interaction. On the other hand, there is no the feedback which has very important role in the classroom interaction. Teachers only ask questions without giving the feedback as Sinclair and Coulthard Model does. Students mostly use Initiation (I) and Initiation-Feedback (IF) in the classroom. The feedback was not gotten from the teachers but it was from among students.

2. The underlying reasons of teacher's performance were affected by presage and context category. Both teachers have not fully conducted based on what curriculum 2013 does which asking question is the first step in the classroom 
interaction. Teachers only focus on giving information. On the other hand, the reasons of student's performance were affected by students' thought processes category. Then, the students' thought processes category appears as their reason that the teachers' teaching method is inappropriate for them which is teacher is dominant in the class.

\section{Suggestions}

1. A. Teachers

1.1 The teacher is expected to improve the effectiveness of teaching both in English classroom and Mathematics classroom as what curriculum 2013 does which is student-centered learning every subject while conducting the classroom activities.

1.2 Teachers must consider the activities and interaction in the classroom through IRF Pattern and Gender of the students in verbal classroom discourse. Teachers should incorporate real life like activities into their teaching practice.

B. Students

1.3 The students can have a chance to talk and explore their ideas and cooperate in the learning process in order to scaffold their ideas by involving the classroom discussion.

\section{A. Teachers}

2.1 Teachers must deepen their knowledge about lesson for the teacher about Critical pedagogy to support their teaching method in the classroom. 
2.2 It is suggested to other researchers to conduct further studies in classroom discourse whether it is based on Sinclair and Coulthard model, which will be a very useful reference to the students' needs in teaching learning process related to teachers' performances.

B. Students

2.3 The students should improve their abilities and ways in learning English so that they will be enthusiastic and be motivated to participate actively in the classroom activities

\section{REFERENCES}

Auerbach, C, F, and Silverstein. I. B. (2003). An Introduction to coding and Analysis Qualitative. New York: New York University

Coulthard, M. (1992). Advances in spoken discourse analysis. London: Routledge

Gage, N, L. 2009. A Concept of Teaching. USA: Springer Science + Busniess Media, LLC.

Markee, N. (2015). The Handbook of Classroom Discourse and Interaction. United Kingdom: John Wiley \& Sons.

Rymes, B. (2008). Classroom discourse analysis: A tool for critical reflection. Cresskill, NJ: Hampton Press.

Walsh, S. (2006) Investigating Classroom Discourse, London: Routledge. 